\title{
Organ Donor Risk Stratification in Italy
}

\author{
Adriano Peris, Jessica Bronzoni, Sonia Meli, \\ Juri Ducci, Erjon Rreka, Davide Ghinolfi, \\ Emanuele Balzano, Fabio Melandro, \\ and Paolo De Simone
}

\subsection{Background}

\subsubsection{The Donor Risk}

Assessment of suitability of organ and tissue donors is aimed at the best donor-to-recipient matching and minimization of the risk of disease transmission. Basically, there are two types of communicable disease: infectious and neoplastic. In addition, some toxic agents (i.e., acute poisoning of the organ donor) can inadvertently be

\footnotetext{
A. Peris

Organizzazione Toscana Tapianti, The Regional Health Ministry, Florence, Italy

J. Bronzoni · S. Meli

Hepatobiliary Surgery and Liver Transplantation, University of Pisa Medical School Hospital,

Pisa, Italy

University of Pisa, Pisa, Italy

J. Ducci · E. Rreka · D. Ghinolfi · E. Balzano

F. Melandro

Hepatobiliary Surgery and Liver Transplantation, University of Pisa Medical School Hospital,

Pisa, Italy

\section{P. De Simone $(\bowtie)$}

Hepatobiliary Surgery and Liver Transplantation, University of Pisa Medical School Hospital,

Pisa, Italy

Department of Surgical, Medical and Molecular Pathology and Intensive Care, University of Pisa, Pisa, Italy

e-mail: paolo.desimone@unipi.it;
}

transmitted to graft recipients. In the setting of organ transplantation, disease transmission may be intentional (i.e., deliberate, anticipated) or inadvertent (Table 23.1).

For instance, use of hepatitis $\mathrm{C}$ positive (HCV) liver grafts may be contemplated for HCV-positive liver recipients due to recent availability of pangenotypic, direct acting antivirals (DAA). In such cases, the risk of viral transmission is considered minimal with respect to the anticipated benefit for the transplant recipient. The higher the need of transplantation for a given patient, the greater is the risk that can potentially be taken: i.e., risk assessment requires evaluation of both donors and recipients. The organ donor evaluation process entails collection of available information, laboratory investigations, clinical examinations, and surgical exploration findings. It is intrinsically multidisciplinary and multiphase, and its span ranges from donor referral to longterm survival of organ recipients. Transmissible disease is any condition for which available scientific evidence or clinical reports confirm the risk of transmission. In clinical practice, however, communicable disease is the one that is considered such by clinical experts or whose risk of transmission cannot entirely be excluded.

In Italy, the donor risk assessment process is based on guidelines provided to all transplant network professionals by the national agency for transplantation (Centro Nazionale Trapianti, CNT). Due to complexity of clinical practice, 
Table 23.1 Categories of donor-derived disease transmission in organ transplantation

\begin{tabular}{l|l|l}
\hline Category & Definition & Instances \\
\hline Inadvertent & $\begin{array}{l}\text { Unintentional transmission of infections, } \\
\text { malignancies or toxic agents from organ donors to } \\
\text { recipients }\end{array}$ & $\begin{array}{l}\text { Transmission of unknown donor } \\
\text { hepatocellular carcinoma or HIV infection }\end{array}$ \\
\hline Intentional & $\begin{array}{l}\text { Anticipated transmission based on possibility of } \\
\text { treatment and/or benefit for the recipient }\end{array}$ & $\begin{array}{l}\text { ver transplantation from HBsAg, anti-HBc } \\
\text { or anti-HCV-positive donors } \\
\text { Transplantation from donors with low-grade } \\
\text { malignancies (i.e., skin, kidney, prostate) }\end{array}$ \\
\hline
\end{tabular}

Table 23.2 The basic principles of the donor risk evaluation process

\begin{tabular}{l|l}
\hline$\#$ & Definition \\
\hline 1 & $\begin{array}{l}\text { No donor can be excluded from evaluation unless } \\
\text { there is any clinical condition contraindicating } \\
\text { donation (i.e., metastatic malignancy) }\end{array}$ \\
\hline 2 & The risk is never zero \\
\hline 3 & $\begin{array}{l}\text { Risk evaluation is an ongoing process based on } \\
\text { available clinical information }\end{array}$ \\
\hline
\end{tabular}

however, consultation with national experts in infectious disease, pathology, hematology, and legal issues has been provided on a routine basis since 2004 to assist transplant professionals.

\subsubsection{The Principles of Donor Risk Evaluation}

There are three basic tenets in the donor evaluation process (Table 23.2). Firstly, in the absence of formal contraindications to donation (i.e., active systemic infections from multidrugresistant bacteria or invasive malignancies with metastatic dissemination), the risk of disease transmission must be assessed against the potential benefit for the transplant recipient. Apart from a limited number of clinical conditions unfit to donation (unacceptable risk), no donor can be excluded from evaluation and their organs might benefit potential candidates. Secondly, patients awaiting organ transplantation must be informed that the risk of disease transmission is small but finite (standard risk). Finally, risk evaluation is an ongoing process based on information collected longitudinally after transplantation. To this regard, CNT is committed to updating of current guidelines based on clinical data derived from clinicians and on evaluation of posttransplant graft and patient survival rates.
Table 23.3 The donor risk evaluation algorithm

\begin{tabular}{l|l|l}
\hline Phase & $\#$ & Definition \\
\hline Pretransplant & 1 & Clinical history \\
\cline { 2 - 3 } & 2 & Physical exam \\
\cline { 2 - 3 } & 3 & Laboratory and imaging \\
\cline { 2 - 3 } & 4 & Surgery \\
\hline Posttransplant & 5 & $\begin{array}{l}\text { Ongoing clinical evaluation } \\
\text { and prompt reporting of } \\
\text { adverse events }\end{array}$ \\
\hline
\end{tabular}

\subsubsection{The Risk Evaluation Process}

The donor risk evaluation process is multiphase and multidisciplinary and involves all healthcare professionals along the entire continuum of the donation-transplantation journey. Risk assessment is based on the following (Table 23.3).

\subsubsection{Organ Procurement}

(a) Donor's clinical history, with special focus on infectious diseases and malignancies. This entails use of all available sources of information (attending physicians; family members; healthcare staff, etc.), and attention should be paid to (1) sexual habits; (2) use of drugs; (3) travels to areas with endemic infectious disease (i.e., malaria; West Nile virus; trypanosomiasis); (4) bite-marks (dogs; bats; hamsters, etc.), and (5) previous or current disease of infectious, neoplastic or autoimmune etiology.

(b) Donor's physical examination: This should focus on the presence of scars (i.e., previous surgeries), skin or mucous lesions with special attention to: (1) tattoos; (2) jaundice; (3) rashes (especially in infants and children); (4) lymph node enlargement; and (5) signs of active drug use (venipuncture). Exploration of thyroid, breast, testes, superficial lymph 
nodes and rectal examination is strongly recommended if the donor is $>50$ years.

(c) Laboratory and imaging: There is great variability in number and type of investigations as per local clinical practice, but the basic set should include blood count; kidney and liver function tests; and HBV, HCV, HIV serology. Additional tests may be contemplated, based on local practice or individual donor's clinical conditions. In the presence of massive blood and fluid administration (i.e., traumas), all viral serology should be interpreted with care. Current European Union directives recommend long-term storage of a whole blood or buffy coat sample of both donor and recipient for longitudinal risk assessment.

(d) Donor surgery: Irrespective of number and type of procured organs, surgeons are requested to explore thoracic and abdominal organs, including kidneys in case of anticipated lack of allocation. Exploration should be combined with sampling and biopsies when needed.

\subsubsection{Posttransplant Course}

Continued monitoring of transplant recipients and prompt reporting of donation-related and unrelated adverse events is crucial to collection of evidence and updating of current recommendations.

\subsubsection{The Donor Risk Categories}

Based on procurement data and information, any referred donor can be further categorized in one of the following (Table 23.4):

1. Standard-risk donor: this group includes any organ donor with no particular disease transmission risk. The probability of disease transmission is extremely low, but not zero.

2. Nonstandard-risk donor: This group is further divided into:

(a) Donor with a negligible risk profile: This category includes donors with disease that either will not affect the posttransplant graft and patient outcome or do not require special treatment versus standardrisk donors.

(b) Donor with an acceptable risk profile: In these cases, use of organs is based on availability of treatment (i.e., antihepatitis $\mathrm{B}$ virus (HBV) prophylaxis for recipients of $\mathrm{HBsAg}$ and/or anti-HBc donor organs) or benefit to recipients (i.e., risk of dropout from the waiting list due to native disease progression). In both cases, recipients shall be informed at the time of wait listing and transplantation and informed consent is to be docu-

Table 23.4 The donor risk categories according to the Italian Center for Transplantation (CNT)

\begin{tabular}{l|l|l}
\hline Risk category & Definition & Organ allocation \\
\hline Standard & $\begin{array}{l}\text { No risk factors have been detected during donor } \\
\text { referral evaluation and procurement }\end{array}$ & No restriction \\
\hline Nonstandard & $\begin{array}{l}\text { Negligible } \\
\text { Presence of disease that will not affect transplant } \\
\text { outcome or require treatment (i.e., skin basalioma, } \\
\text { low-Gleason score prostate cancer) }\end{array}$ & $\begin{array}{l}\text { No restriction } \\
\text { Informed consent required }\end{array}$ \\
\hline $\begin{array}{l}\text { Acceptable } \\
\text { Presence of disease that might affect transplant } \\
\text { outcome if untreated (i.e., transplantation from } \\
\text { HBsAg and/or anti-HBc and/or anti-HCV-positive } \\
\text { donors) }\end{array}$ & $\begin{array}{l}\text { Selection of appropriate transplant } \\
\text { recipients is required (i.e., anti-HCV- } \\
\text { positive recipients for anti-HCV-positive } \\
\text { donors) } \\
\text { Posttransplant treatment should be } \\
\text { implemented } \\
\text { Informed consent required }\end{array}$ \\
\cline { 2 - 4 } & $\begin{array}{l}\text { Acceptable for patients in relative clinical urgency } \\
\text { Presence of disease that might affect transplant } \\
\text { outcome }\end{array}$ & $\begin{array}{l}\text { Allocation directed to recipients at risk } \\
\text { of disease progression and waitlist } \\
\text { dropout } \\
\text { Informed consent required }\end{array}$ \\
\hline Unacceptable & $\begin{array}{l}\text { Presence of risk factors of communicable, ominous } \\
\text { disease (i.e., metastatic malignancy) }\end{array}$ & \begin{tabular}{l} 
Avoid transplantation \\
\hline
\end{tabular}
\end{tabular}


mented in their clinical records. The category of acceptable risk profile also includes transplantation for patients in relative clinical urgency, i.e., those with severe clinical status, impending disease progression, and consequent risk of dropout from the waiting list (e.g., advanced hepatocellular carcinoma, high model for end-stage disease (MELD) liver transplant candidates or long-standing kidney transplant patients with pretransplant sensitization).

3. Unacceptable-risk donor: This group includes donors with overt risk factors for disease transmission, with special regard to active infectious disease from multidrugresistant bacteria and metastatic malignancies. In such cases we assume that the risk of transplantation greatly exceeds the benefits of dying on the transplant waiting list.

\subsection{Discussion}

Organ transplantation carries a small but finite risk of disease transmission $[1,2]$. The risk of transmission of malignancies in organ transplantation is currently estimated between $0.01 \%$ and $0.05 \%[1,2]$ when strict criteria for donor selection and evaluation are implemented. In such series [3, 4], only one case of melanoma is reported, thus underscoring the benefit of transplantation as compared to a $2 \%$ mortality risk for kidney and up to $17 \%$ for liver waitlist candidates in the same study period. On the opposite, lack of guidelines and inaccurate medical histories are at the basis of case reports of donor-to-recipient transmission of malignancies [5-19].

Due to stagnant donation rates, donor selection criteria have been expanded and use of nonstandard risk donors has been introduced in many countries [20]. This clearly poses considerable ethical issues that should be analyzed and taken into consideration by the competent authorities and institutions. In Italy, introduction of donor risk categories in 2004 has allowed safe use of organs from donors with malignancies, HBsAg and/or anti-HBc donors and, recently, from anti-
HCV-positive and HCV RNA-positive donors in negative recipients in light of the availability of DAAs for hepatitis $\mathrm{C}$ treatment with no negative impact on the overall graft and patients survival rates [20].

Implementation of national guidelines and risk stratification has been crucial to achievement of favorable results. This underlies the important role of regional and national authorities/agencies and of multidisciplinary integration of all healthcare professionals along the entire continuum of the donation-transplantation process. Retrieval of clinical information can be challenging in the setting of donation after brain death (DBD) and even more in the setting of uncontrolled donation after cardiocirculatory death (uDCD), when time pressure urges professionals to achieve results (i.e., organ procurement) as quickly as possible. To this regard, active participation of donor families, general practitioners, and healthcare institutions to the donation process is pivotal to an efficient algorithm and reduction of the uncertainty margin to the lowest level (standard risk). Organ donation is truly an instance of social enterprise, and relies on efficient integration of all levels of care (primary, secondary, and tertiary). Risk control strategies can be effective only if based on comprehensive policies encompassing the entire spectrum of the donationtransplantation process.

\section{References}

1. Kauffman HM, McBride MA, Cherikh WS, Spain PC, Delmonico FL. Transplant tumor registry: donor related malignancies. Transplantation. 2002;74:358-62.

2. Desai R, Collett D, Watson CJ, Johnson P, Evans T, Neuberger J. Cancer transmission from organ donors - unavoidable but low risk. Transplantation. 2012;94:1200-7.

3. Desai R, Collett D, Watson CJE, Johnson P, Evans T, Neuberger J. Estimated risk of cancer transmission from organ donor to graft recipient in a national transplantation registry. BJS. 2014;101:768-74.

4. Kauffman HM, Cherikh WS, McBride MA, Cheng Y, Hanto DW. Deceased donor with a past history of malignancy: an Organ Procurement and Transplantation Network/United Network of Organ Sharing update. Transplantation. 2007;84:272-4. 
5. Sack FU, Lange R, Mehmanesh H, Amman K, Schnabel P, Zimmermann R, Dengler T, Otto HF, Hagl S. Transferral of extrathoracic donor neoplasm by the cardiac allograft. J Heart Lung Transplant. 1997;16(3):298-301.

6. Barrou B, Bitker MO, Delcourt A, Ourahma S, Richard F. Fate of renal tubulopapillary adenoma transmitted by an organ donor. Transplantation. 2001;72(3):540-1.

7. Llamas F, Gallego E, Salinas A, Virseda J, Pérez J, Ortega A, Nam SH, Gómez C. Sarcomatoid renal cell carcinoma in a renal transplant recipient. Transplant Proc. 2009;10:4422-4.

8. Ferreira GF, Azevedo de Oliveira R, Jorge LB, Nahas WC, Saldanha LB, Ianhez LE, Srougi M. Urothelial carcinoma transmission via kidney transplantation. Nephrol Dial Transplant. 2010;25:641-3.

9. Forbes GB, Goggin MJ, Dische FE, Saeed IT, Parsons V, Harding MJ, Bewick M, Rudge CT. Accidental transplantation of bronchial carcinoma from a cadaver donor to two recipients of renal allografts. J Clin Pathol. 1981;34(2):109-15.

10. Winter TC, Keller PR, Lee FT Jr, Pozniak MA. Donorderived malignancy: transmission of small-cell lung cancer via renal transplantation. J Ultrasound Med. 2001;20(5):559-62.

11. Lipshutz GS, Baxter-Lowe LA, Nguyen T, Jones KD, Ascher NL, Feng S. Death from donor-transmitted malignancy despite emergency liver retransplantation. Liver Transpl. 2003;9(10):1102-7.

12. Nair BT, Bhat SH, Narayan UV, Sukumar S, Saheed M, Kurien G, Sudhindran S. Donate organs not malignancies: postoperative small cell lung carcinoma in a marginal living kidney donor. Transplant Proc. 2007;39(10):3477-80.

13. Zelinkova Z, Geurts-Giele I, Verheij J, Metselaar H, Dinjens W, Dubbink HJ, Taimr P. Donor-transmitted metastasis of colorectal carcinoma in a transplanted liver. Transpl Int. 2012;25(1):e10-5.

14. Ison MG, Nalesnik MA. An update on donor-derived disease transmission in organ transplantation. Am J Transpl. 2011;11:1123-30.

15. Zwald FO, Christenson LJ, Billingsley EM, Zeitouni NC, Ratner D, Bordeaux J, Patel MJ, Brown MD, Proby CM, Euvrard S, Otley CC, Stasko T, Melanoma Working Group of the International Transplant Skin Cancer Collaborative and Skin Care in Organ Transplant Patients, Europe. Melanoma in solid organ transplant recipients. Am J Transplant. 2010;10(5):1297-304.

16. Strauss DC, Thomas M. Transmission of donor melanoma by organ transplantation. Lancet Oncol. 2010;11:790-6.

17. MacKie RM, Reid R, Junor B. Fatal melanoma transferred in a donated kidney 16 years after melanoma surgery. N Engl J Med. 2003;348:567-8.

18. Bajai NS, Watt C, Hadjiliadis D, Gillespie C, Haas AR, Pochettino A, Mendez J, Sterman DH, Schuchter LM, Christie JD, Lee JC, Ahya VN. Donor transmission of malignant melanoma in a lung transplant recipient 32 years after curative resection. Transpl Int. 2010;23(7):e26-31.

19. Braun-Parvez L, Charlin E, Caillard S, Ducloux D, Wolf P, Rolle F, Golfier F, Flicoteaux H, Bergerat JP, Moulin B. Gestational choriocarcinoma transmission following multiorgan donation. Am J Transplant. 2010;10(11):2541-6.

20. Petrini C, Trapani S, Riva L, Floridia G, Gainotti S, Lombardini L, Masiero L, Rizzato L, Costa AN. Organ transplantation from nonstandard risk donors: midway between rigid and flexible rules. Transplant Proc. 2019;51(9):2856-9.

Open Access This chapter is licensed under the terms of the Creative Commons Attribution 4.0 International License (http://creativecommons.org/licenses/by/4.0/), which permits use, sharing, adaptation, distribution and reproduction in any medium or format, as long as you give appropriate credit to the original author(s) and the source, provide a link to the Creative Commons license and indicate if changes were made.

The images or other third party material in this chapter are included in the chapter's Creative Commons license, unless indicated otherwise in a credit line to the material. If material is not included in the chapter's Creative Commons license and your intended use is not permitted by statutory regulation or exceeds the permitted use, you will need to obtain permission directly from the copyright holder. 